\title{
CFD Modelling of The Airflow in The Driver's Cabin of a Modern Rail Vehicle
}

\author{
Agnieszka Palmowska, Katarzyna Walczyk \\ Silesian University of Technology, Department of Heating, Ventilation and Dust Removal Technology \\ Konarskiego 20, Gliwice, Poland \\ agnieszka.palmowska@polsl.pl
}

\begin{abstract}
One of the important applications of CFD technique is modelling of the air distribution systems in ventilated and airconditioned areas. In this paper, numerical modelling was used to predict airflow in the air-conditioned driver's cabin of a modern rail vehicle. The aim of this study was to investigate indoor thermal and humidity conditions with the use of ANSYS CFX code. Therefore, the numerical model of the cabin was prepared in the presence of a driver. The boundary conditions were developed on the basis of the heat and moisture balance of the object. The air parameters like temperature, humidity and velocity were verified. Particular attention was paid to maintenance of optimal internal conditions due to the presence of a driver for 6 different cases of air distribution. The simulation results were compared with direct calculation results. For each of the studied cases, there were substantial differences in the distributions of air velocity and temperature. In any case, the maximum permissible air temperature and humidity were not exceeded globally. The recommended air velocities were exceeded locally.
\end{abstract}

Keywords: Numerical modelling CFD, Rail, Vehicle, Locomotive, Conditioning, Ventilation, Air distribution, Thermal and humidity conditions.

\section{Introduction}

The proper operation of heating, ventilation and air conditioning (HVAC) systems in modern rail vehicles has a significant impact on comfort of the staff and traveling conditions of passengers. This issue is an important challenge for the constructors of these vehicles. Based on our own experience, it was found that the design of HVAC systems may be a source of difficulties and doubts. It is difficult to predict the effects of these systems by using traditional engineering methods. In addition, it is crucial to identify potential failures at the early stage of the design, even before developing a prototype of the machine. Making changes to an existing vehicle is difficult, expensive, and sometimes straight impossible. Further, in practice, this requires stopping the work of vehicles for a long time or interfering with the construction of the vehicle. Experimental research, however possible, entails a huge cost and still requires a prototype to be performed.

It is, therefore, necessary to use Computational Fluid Dynamics (CFD) technique, based on the basic equations of fluid flow and heat. This method is particularly applicable where measurements in the facility are difficult or impossible to carry out, and where traditional engineering methods do not work [1]. It requires a good definition of the tested object (boundary conditions) and model validation. CFD modelling is a useful tool for the optimization of HVAC systems for cabins from the perspective of user requirements. Constructors could benefit from CFD method by:

- improving HVAC systems performance;

- $\quad$ assessing and reducing the risk of failures;

- decreasing the cost and time of project (reduced number of prototypes);

- enabling to find innovative solutions.

There are more objectives for CFD in the railway industry, such as aerodynamic performance prediction, external aero-thermal flow characterization, fire extinction, aero-acoustic and many more.

Based on the literature review, it was found out that researchers focused their attention on motorization and HVAC systems mainly for automobile cabins, for example [2], [3], [4], [5], [6], [7]. For the railway industry, CFD simulation tend to focus on airflow simulations in carriages, for example [8], [9].

The driver's cabin is part of the rail vehicle intended for the crew in which supervision of the equipment operation is performed. This kind of indoor environment is poorly recognized and underpinned by HVAC research. In the literature only a few experimental tests on their air-conditioner systems can be found [10], [11], however, they do not concern directly the indoor environment issue. Many simulation results are commercial and not scientific, thus they 
could not be published. Nevertheless, cabins are the driver's place of work, hence the need to provide them with the right indoor conditions. Otherwise, drivers can become fatigued easily. A comfortable vehicular climate not only helps to reduce the driver stress but also guarantees good visibility by avoiding the fog phenomenon, and thus contributing to safer driving [5]. It is also important due to the fact that rail freight transport is widely used and prevalent in many countries around the world. For example, it is the major mode of transport in China, where the total movement of goods using rail was over 2,300,000 million tonne-kilometers in 2016 [12]. For comparison, in Poland, the average transport work is about 50,000 million tonne-kilometers per year [13]. At this point, it should be emphasized that any problems with HVAC systems in the cabins, causing the inability of drivers to work, entail huge financial losses, which in practice fall on locomotive producers.

The aim of this paper was preliminary examination and recognition of problems related to indoor thermal and humidity conditions in the driver's cabin of a modern locomotive during air conditioning system operation for different cases of air distribution. The purpose of simulations was not to achieve precise numerical results, but only to check whether results indicate incorrect indoor conditions based on an approximate model. Moreover, study results will be helpful in the near future to target a validation experiment plan.

\section{HVAC systems of a locomotive driver's cabin - specification and requirements}

The HVAC system in locomotive should fulfill the following basic functions:

- providing adequate thermal and humidity conditions for driver/drivers of the vehicle;

- maintaining the $\mathrm{CO}_{2}$ concentration at an appropriate level.

Driving cabs are classified in categories A and B, according to EN 14813-1 [14], depending on the cabin's volume and occupant residence time. Different required parameters of thermal comfort are defined for them. The comfort criteria of category A are usually applicable both to main line and suburban trains, while driving cabs in urban trains fall into category B, especially when not separated from the passenger area by a wall [15]. The minimum value of the indoor air temperature (at the minimum outdoor air temperature, the maximum operating speed of the vehicle, no solar load, no users) is $18^{\circ} \mathrm{C}$. Maximum indoor temperature value (at the maximum outdoor temperature, in a stationary vehicle, with solar load, with users) depends on the climatic zone (Table 1). Central European countries are assigned to Zone II. The minimum and maximum air velocity at the measurement points specified in EN 14813-2 [16] depends on the categories $\mathrm{A}$ and $\mathrm{B}$ and the air temperature in the cabin, for example, maximum value equals to $0.3 \mathrm{~m} / \mathrm{s}$ for category $\mathrm{A}$ and for the temperature of $24^{\circ} \mathrm{C}$ (at driver's head). Relative air humidity should not exceed $50-60 \%$ for category A and $60-90 \%$ for category $\mathrm{B}$, depending on the indoor air temperature (Table 1).

Table 1: Design conditions for maximum mean interior temperature/relative humidity [15].

\begin{tabular}{|c|c|c|c|}
\hline \multicolumn{2}{|c|}{ Climatic zones (summer) } & \multicolumn{2}{c|}{ Maximum mean interior temperature/relative humidity } \\
\hline Zone & $\begin{array}{c}\text { Temperature/relative humidity; } \\
\text { equivalent solar load }\end{array}$ & Category A & Category B \\
\hline I & $+40^{\circ} \mathrm{C} / 40 \% ; 800 \mathrm{~W} / \mathrm{m}^{2}$ & $+27^{\circ} \mathrm{C} / 50.0 \%$ & $+30^{\circ} \mathrm{C} / 60.0 \%$ \\
\hline II & $+35^{\circ} \mathrm{C} / 50 \% ; 700 \mathrm{~W} / \mathrm{m}^{2}$ & $+26^{\circ} \mathrm{C} / 52.5 \%$ & $+28^{\circ} \mathrm{C} / 65.0 \%$ \\
\hline III & $+28^{\circ} \mathrm{C} / 45 \% ; 600 \mathrm{~W} / \mathrm{m}^{2}$ & $+22^{\circ} \mathrm{C} / 60.0 \%$ & $+24^{\circ} \mathrm{C} / 75.0 \%$ \\
\hline
\end{tabular}

Vertical temperature distribution in the occupied zone should be at most $3 \mathrm{~K}$ and $6 \mathrm{~K}$, for category $\mathrm{A}$ and $\mathrm{B}$, respectively, in order to reduce the areas of local thermal discomfort to a minimum. A defined amount of fresh air must also be supplied. The value required in the standards [14] is $30 \mathrm{~m}^{3} / \mathrm{h} /$ person if the driver's cab is air-conditioned. High levels of $\mathrm{CO}_{2}$ give rise to fatigue and impaired concentration and create an atmosphere that feels stuffy and stale [15].

\section{Methods}

\subsection{Investigated cabin and its CFD model}

A driver's cabin of the modern rail vehicle was used in this research. Its numerical model was developed based on the cabin of ET22-2000 electric locomotive (Fig. 1) and prepared with the use of ANSYS Design Modeler. A modern streamlined shape was given by rounding the walls and modifying the front glazing (Fig. 2). It was assumed that there may be two people inside: driver and assistant, of which only the driver was included in the model in detail (Fig. 2). 
The model took into account typical equipment for the driver's cabin with a control panel and two seats (for driver and assistant). The designed model had external dimensions: $2.96 \times 2.04 \mathrm{~m}$ (length $\times$ width) and $2.22 \mathrm{~m}$ of clear height.

The supply air system $v$
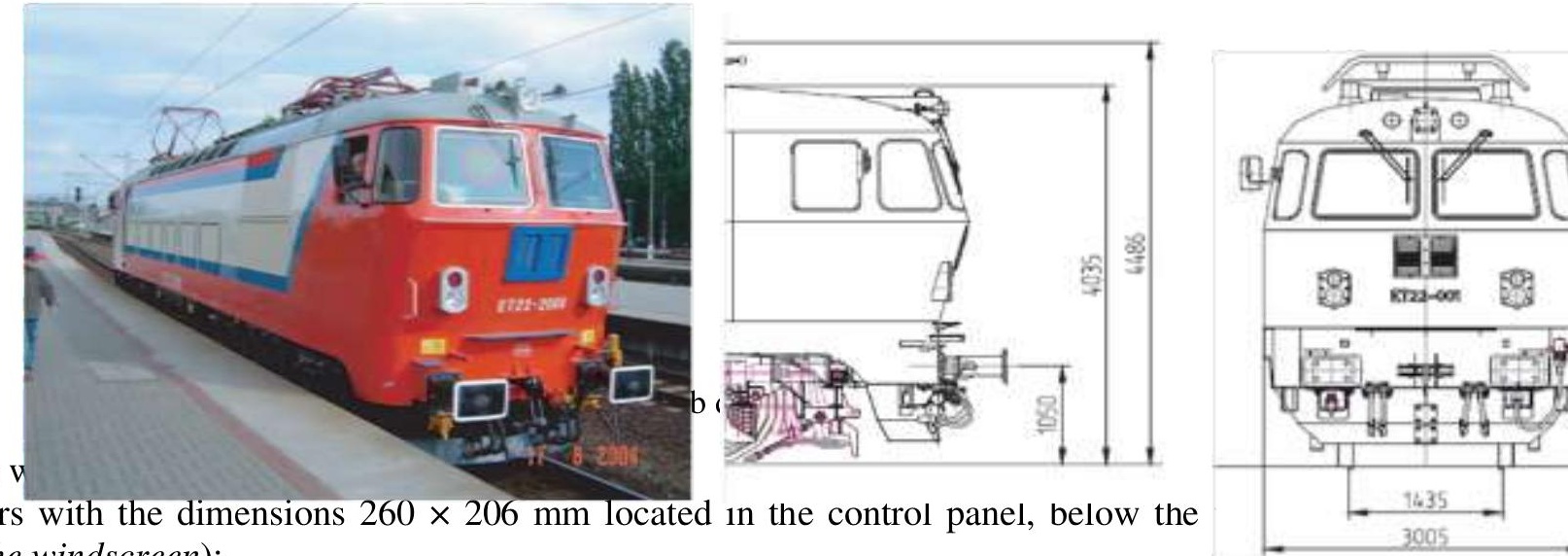
supply onto the windscreen);

- 4 rectangular grilles ( 2 per each side) with the dimensions $142 \times 590 \mathrm{~mm}$ placed on the sides of the control panel (air supply onto side windows);

- 2 round grilles with a diameter of $100 \mathrm{~mm}$ placed under the control panel, in the middle part of the cabin (air supply onto the driver);

- 2 round grilles with a diameter of $100 \mathrm{~mm}$ placed under the control panel at the level of the calves of the driver, near the side walls (air supply onto the driver's feet).

As a rule, the cabin is maintained in a positive pressure system (air discharge occurs through the leakage of doors and windows), which was not included in the numerical calculations, just as air recirculation.

\subsection{Grid data and convergence conditions}

An unstructured grid was used to mesh numerical model of driver's cabin. The best possible mesh settings on the available server were applied: the basic mesh size was $10 \mathrm{~cm}$, with a local refinement around inlets and driver. Five layers consisting of prismatic elements, with a total maximum thickness of $5 \mathrm{~cm}$ in the boundary layer at the surface of the partitions were included. The total number of elements was 4084604, including 3733080 tetrahedral elements. The calculations were considered to reach convergence when residuals become less than $1.0 \mathrm{E}-4$ for heat transfer and mass fractions and 1.0E-6 for other variables.

\subsection{Boundary conditions and design assumptions}

The boundary conditions were based on the heat and humidity balance of the object according to standards [14], [16]. The tested driver's cabin with a capacity of $11.57 \mathrm{~m}^{3}$ belongs to A category. It was assumed that the vehicle is used in Poland. According to EN 14813-1 [14] in the summer it is Zone II with outdoor air parameters: temperature of $35^{\circ} \mathrm{C}$, relative humidity of $50 \%$ and a solar load of $700 \mathrm{~W} / \mathrm{m}^{2}$. The designed air condition in the cabin was: temperature of $24^{\circ} \mathrm{C}$ and relative humidity of $57 \%$.

The heat and humidity balance included heat and moisture gains from one person (driver), heat transfer through walls (without an interior wall, for which good thermal insulation was assumed) and heat gains from insolation. The following heat transfer coefficients were set: $1.6 \mathrm{~W} / \mathrm{m}^{2} \mathrm{~K}$ for housing, ceiling, and floor; $3.0 \mathrm{~W} / \mathrm{m}^{2} \mathrm{~K}$ for doors; 1.5 for windscreen $\mathrm{W} / \mathrm{m}^{2} \mathrm{~K} ; 1.7 \mathrm{~W} / \mathrm{m}^{2} \mathrm{~K}$ for side and door windows. The overall heat transfer coefficient defined in standards characterizes the thermal quality of exterior walls and the effect of air leakages. Its value shall be less than or at least equal to $1.9 \mathrm{~W} / \mathrm{m}^{2} \mathrm{~K}$ (A category, Zone II) and is applicable to all or part of the driving cab [16]. There is no information about the impact of vehicle speed on the real value of this coefficient, however, this study concerned stationary vehicle. All calculated values of heat and moisture gains were presented in Table 2. 

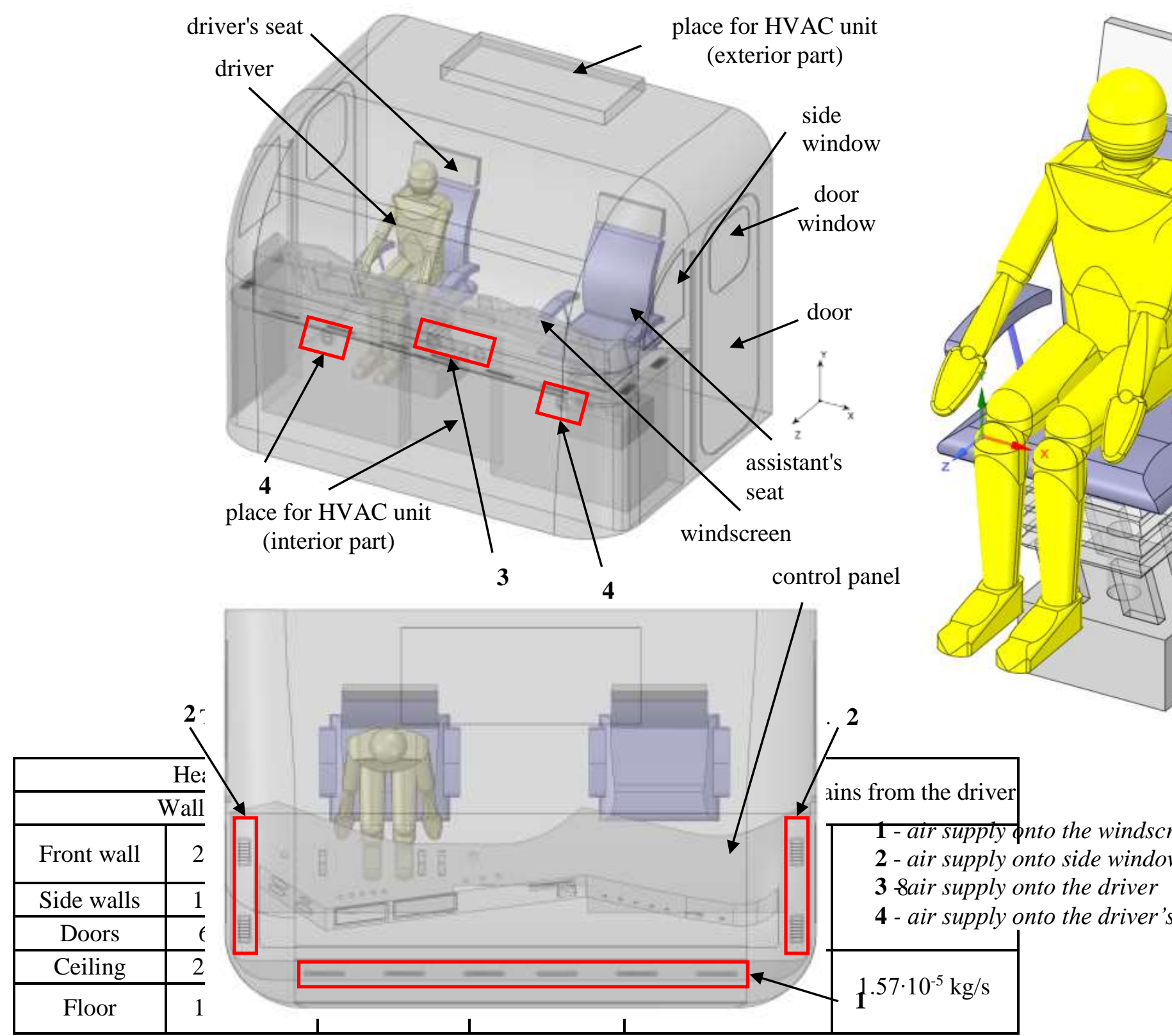

In the numerical model, heat gains were applied to the area of the walls, with the exception of the interior wall, which was defined as adiabatic. The human sensible heat gains were separated into a convective and radiation components with reference to the surface of the driver's model. The flux of moisture was applied.

For design purposes, the air conditioner KLIL 22 was selected [18], with a maximum airflow of $965 \mathrm{~m}^{3} / \mathrm{h}$ $(0.32 \mathrm{~kg} / \mathrm{s})$ and a cooling capacity of $4.2 \mathrm{~kW}$, needed to assimilate heat gains calculated in the balance. Analysis of the air treatment processes using the Mollier chart was carried out in order to get information about air parameters in the supply openings, which were set as follows: temperature of $18^{\circ} \mathrm{C}$ and specific humidity of $0.0108 \mathrm{~kg} / \mathrm{kg}$. Air supplied from the diffusers was directed at an angle of $90^{\circ}$ to the plane of the supply openings. The mass flow of air was set in the supply openings. Different proportions of this flow for particular diffusers were analyzed for 6 cases (Table 3). The driver using the diagnostic screen has the ability to change individual modes of system operation (eg. controlling the level of opening the flap valves for legs, windows, etc.). Individual executive components, such as a fan or the position of airflow control dampers, are managed by the controller.

\subsection{Calculation process}


CFD numerical calculations were performed with the use of ANSYS CFX 14.5 software with the following assumptions: Finite Volume Method, the high resolution discretization scheme, Rhie Chow redistribution algorithm, Shear Stress Transport turbulence model. The thermal radiation was calculated by the Discrete Transfer Model. The simulations have been performed for steady-state, three-dimensional and non-isothermal conditions. Non-slip conditions in near-wall boundary layer were taken into account. Preliminary tests including the choice of turbulence model, solver settings and improvement of the model geometry were carried out.

Table 3: Numerical cases.

\begin{tabular}{|c|c|c|c|c|c|c|c|}
\hline Air supply & $\begin{array}{l}\text { Air mass } \\
\text { flow rate }\end{array}$ & Case & Air supply & $\begin{array}{l}\text { Air mass } \\
\text { flow rate }\end{array}$ & Case & $\begin{array}{c}\text { Total amount } \\
\text { of air supplied onto } \\
\text { windows } \\
\end{array}$ & $\begin{array}{l}\text { Percentage of the total } \\
\text { amount of air supplied } \\
\text { onto windows }\end{array}$ \\
\hline \multirow{6}{*}{$\begin{array}{c}\text { onto } \\
\text { the } \\
\text { windscreen }\end{array}$} & $0.160 \mathrm{~kg} / \mathrm{s}$ & 1 & \multirow{6}{*}{$\begin{array}{c}\text { onto } \\
\text { side } \\
\text { windows }\end{array}$} & $0.128 \mathrm{~kg} / \mathrm{s}$ & 1 & $0.288 \mathrm{~kg} / \mathrm{s}$ & $90 \%$ \\
\hline & $0.138 \mathrm{~kg} / \mathrm{s}$ & 2 & & $0.093 \mathrm{~kg} / \mathrm{s}$ & 2 & $0.231 \mathrm{~kg} / \mathrm{s}$ & $72 \%$ \\
\hline & $0.192 \mathrm{~kg} / \mathrm{s}$ & 3 & & $0.128 \mathrm{~kg} / \mathrm{s}$ & 3 & $0.320 \mathrm{~kg} / \mathrm{s}$ & $100 \%$ \\
\hline & $0.179 \mathrm{~kg} / \mathrm{s}$ & 4 & & $0.000 \mathrm{~kg} / \mathrm{s}$ & 4 & $0.179 \mathrm{~kg} / \mathrm{s}$ & $56 \%$ \\
\hline & $0.320 \mathrm{~kg} / \mathrm{s}$ & 5 & & $0.000 \mathrm{~kg} / \mathrm{s}$ & 5 & $0.320 \mathrm{~kg} / \mathrm{s}$ & $100 \%$ \\
\hline & $0.144 \mathrm{~kg} / \mathrm{s}$ & 6 & & $0.125 \mathrm{~kg} / \mathrm{s}$ & 6 & $0.269 \mathrm{~kg} / \mathrm{s}$ & $84 \%$ \\
\hline Air supply & $\begin{array}{l}\text { Air mass } \\
\text { flow rate }\end{array}$ & Case & Air supply & $\begin{array}{l}\text { Air mass } \\
\text { flow rate }\end{array}$ & Case & $\begin{array}{c}\text { Total amount } \\
\text { of air supplied onto } \\
\text { driver }\end{array}$ & $\begin{array}{l}\text { Percentage of the total } \\
\text { amount of air supplied } \\
\text { onto driver }\end{array}$ \\
\hline \multirow{6}{*}{$\begin{array}{c}\text { onto } \\
\text { the driver }\end{array}$} & $0.016 \mathrm{~kg} / \mathrm{s}$ & 1 & \multirow{6}{*}{$\begin{array}{c}\text { onto } \\
\text { the } \\
\text { driver's } \\
\text { feet }\end{array}$} & $0.016 \mathrm{~kg} / \mathrm{s}$ & 1 & $0.032 \mathrm{~kg} / \mathrm{s}$ & $10 \%$ \\
\hline & $0.045 \mathrm{~kg} / \mathrm{s}$ & 2 & & $0.045 \mathrm{~kg} / \mathrm{s}$ & 2 & $0.090 \mathrm{~kg} / \mathrm{s}$ & $28 \%$ \\
\hline & $0.000 \mathrm{~kg} / \mathrm{s}$ & 3 & & $0.000 \mathrm{~kg} / \mathrm{s}$ & 3 & $0.000 \mathrm{~kg} / \mathrm{s}$ & $0 \%$ \\
\hline & $0.070 \mathrm{~kg} / \mathrm{s}$ & 4 & & $0.070 \mathrm{~kg} / \mathrm{s}$ & 4 & $0.140 \mathrm{~kg} / \mathrm{s}$ & $44 \%$ \\
\hline & $0.000 \mathrm{~kg} / \mathrm{s}$ & 5 & & $0.000 \mathrm{~kg} / \mathrm{s}$ & 5 & $0.000 \mathrm{~kg} / \mathrm{s}$ & $0 \%$ \\
\hline & $0.026 \mathrm{~kg} / \mathrm{s}$ & 6 & & $0.026 \mathrm{~kg} / \mathrm{s}$ & 6 & $0.052 \mathrm{~kg} / \mathrm{s}$ & $16 \%$ \\
\hline
\end{tabular}

\section{Results and discussion}

The results of numerical calculations were developed using the postprocessor of the CFX Ansys code and they are shown in Fig. $3 \div 4$. Figure 3 shows the distribution of particular air parameters in the cabin: velocity and temperature, in the vertical planes for cases $1 \div 4$.

For case 1, a $50 \%$ of supply air was supplied onto the windscreen, $40 \%$ onto side windows and $10 \%$ onto the driver. The air velocity at the windscreen and at the ceiling reached high values, exceeding $2 \mathrm{~m} / \mathrm{s}$. The temperature distribution of the air was relatively uniform, except for the areas near the partitions and around the human body, where radiation interacted. The mean values of air velocity and temperature were $0.60 \mathrm{~m} / \mathrm{s}$ and $24.15^{\circ} \mathrm{C}$, respectively.

Case 2 assumed more even air distribution for each of the diffusers. The mean value of air velocity was $0.54 \mathrm{~m} / \mathrm{s}$. The air temperature distribution was uneven with a clear division into the cooler central part and the warmer remaining part of the cabin. The mean value of this parameter was $24.24^{\circ} \mathrm{C}$.

Case 3 included total airflow onto windows, without any airflow onto the driver. This resulted in increased air velocity along the windscreen, ceiling, and interior wall. The mean value of air velocity and temperature was $0.70 \mathrm{~m} / \mathrm{s}$ and $24.13^{\circ} \mathrm{C}$, respectively.

For case 4, there was no airflow onto side windows, thus there was increased airflow performance for the driver. The distribution of air velocity was very uneven, and high velocity values occurred in the middle of the cabin. The air temperature was in the range of $22 \div 26^{\circ} \mathrm{C}$. The mean values of air velocity and temperature were $0.70 \mathrm{~m} / \mathrm{s}$ and $24.27^{\circ} \mathrm{C}$, respectively. 
a)

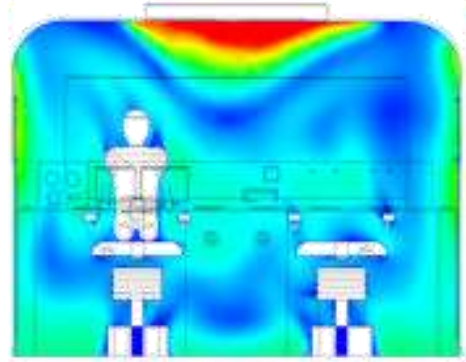

b)

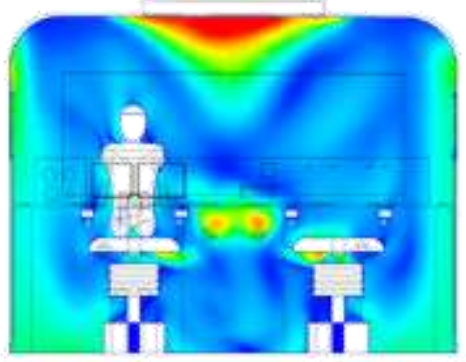

c)

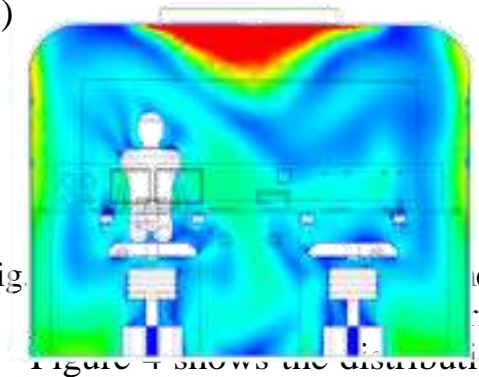

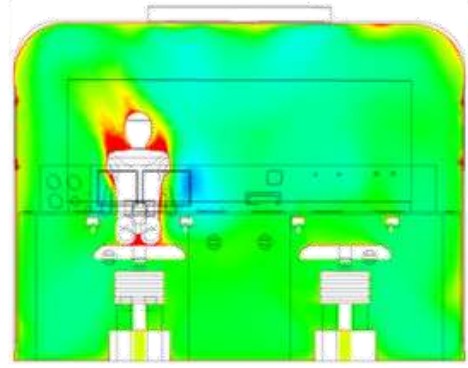
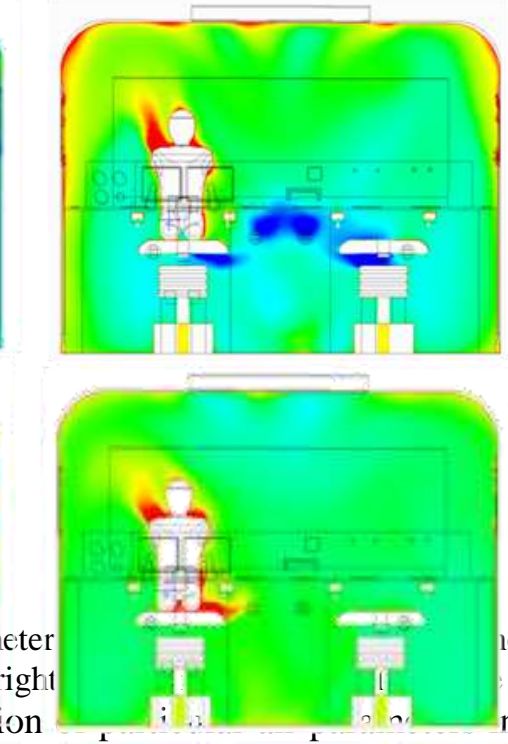
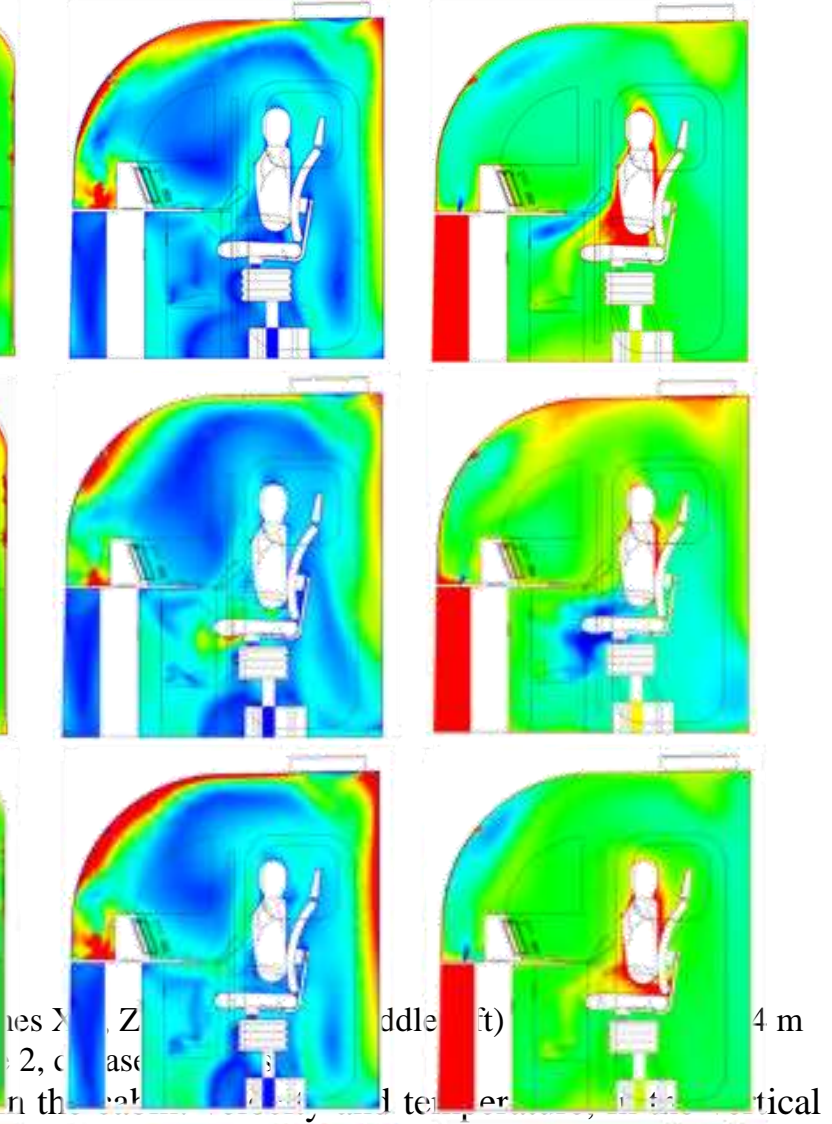
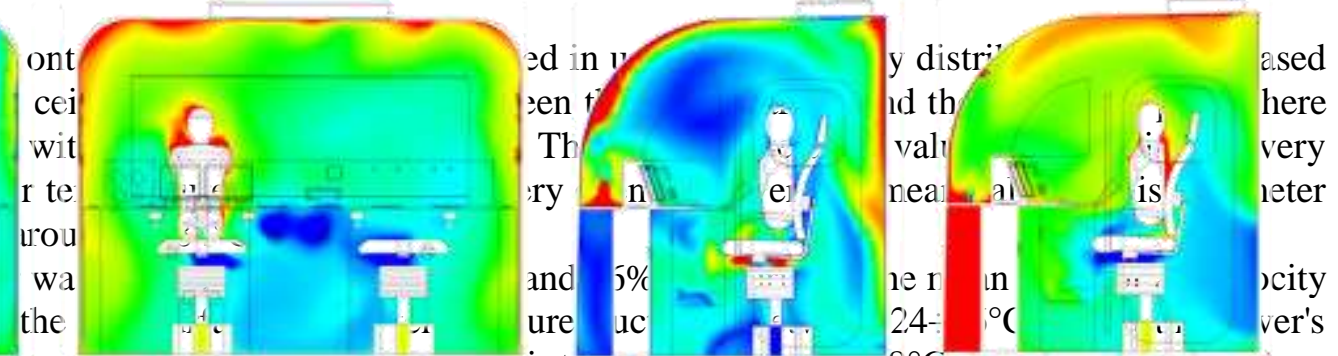

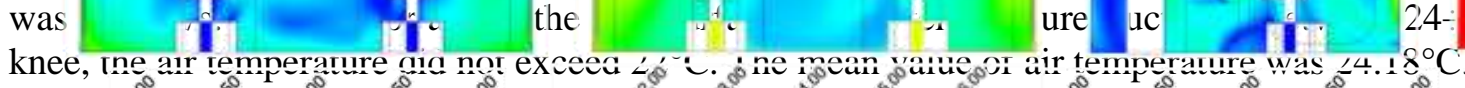

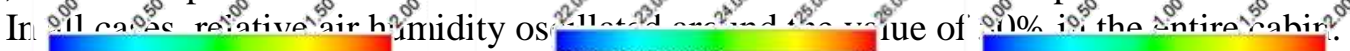

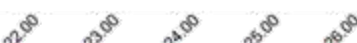

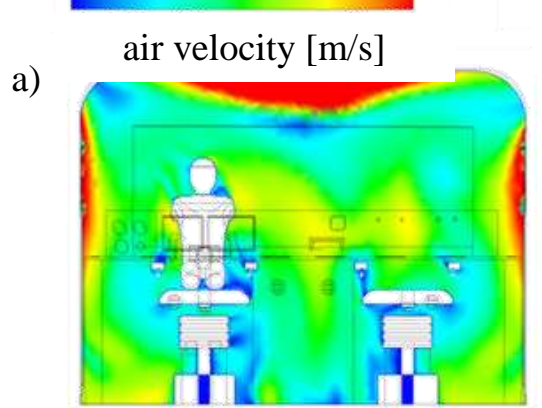

air temperature $\left[{ }^{\circ} \mathrm{C}\right]$

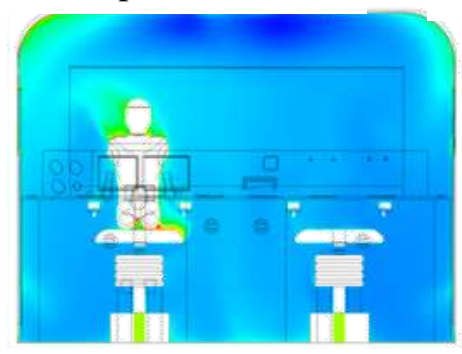

b)

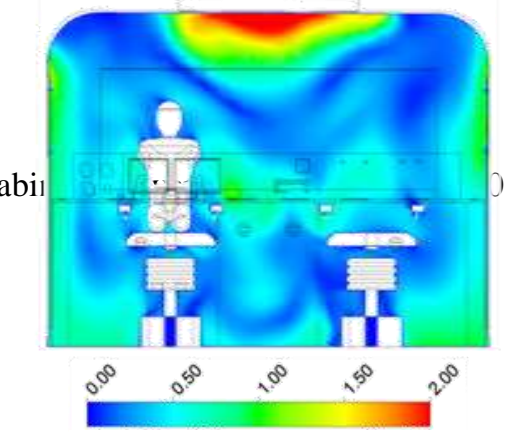

air velocity $[\mathrm{m} / \mathrm{s}]$

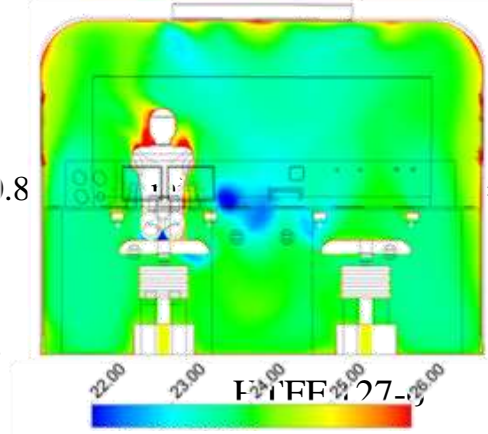

air temperature $\left[{ }^{\circ} \mathrm{C}\right]$ air velocity $[\mathrm{m} / \mathrm{s}]$

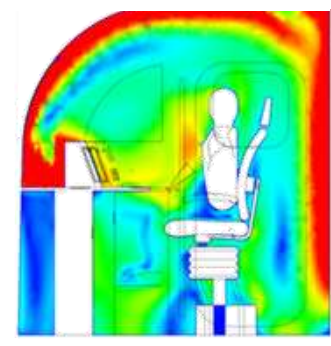

air temperature $\left[{ }^{\circ} \mathrm{C}\right]$

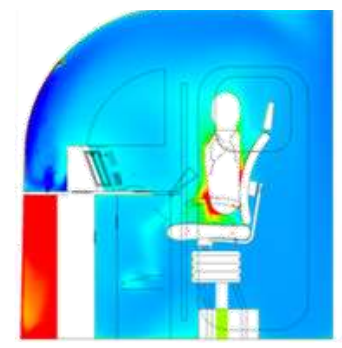

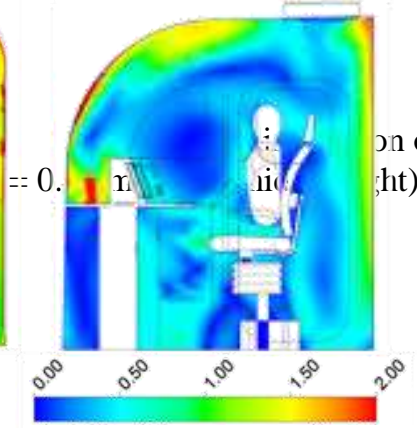

air velocity $[\mathrm{m} / \mathrm{s}]$

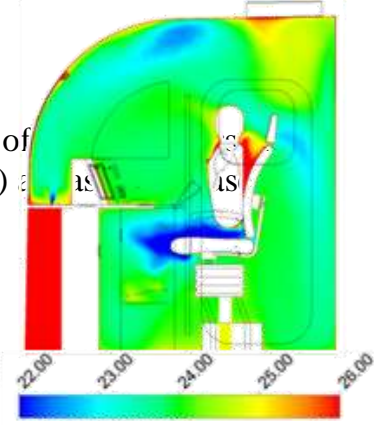

air temperature $\left[{ }^{\circ} \mathrm{C}\right]$ 


\section{Conclusions}

1. Used numerical modelling method allowed to cater for most of the phenomena associated with the flow of air, heat, and moisture in an air-conditioned cabin of the locomotive with a human presence.

2. The results of numerical calculations enabled to see how thermal and humidity conditions are forming inside the studied area.

3. The proper distribution of the airflow across the diffusers is significant for the driver's cab interior conditions.

4. For each of the studied cases, there were substantial differences in the distributions of air velocity and temperature. Case 5 presented most unfavourable air conditions due to significant air turbulence, high air velocities and low temperature within the whole cabin. One of the better solutions was the division of supply air across all diffusers, but with a significant share of the airflow onto the windscreen and low airflow onto the driver (case 1). It allowed for balancing of air velocity in the occupant's zone and obtaining satisfactory air temperature distribution.

5. In any case, the maximum permissible air temperature and humidity were not exceeded globally. The recommended air velocities were exceeded locally. The vertical temperature gradient in the human zone was suitable according to the guidelines. Moreover, the designed air temperature value was obtained in all cases, except case 5, which assumed only airflow onto the windscreen.

6. The numerical model could be useful in the future to help solving the problems related to effectiveness of the HVAC system operation under adequate thermal and humidity conditions for the driver of the locomotive.

7. The CFD model could be also helpful in the near future to planning a validation experiment including detailed measurements of supply air and indoor air parameters as well as external environmental conditions.

\section{Acknowledgements}

This work was supported by own Scholarship Fund of the Silesian University of Technology, in a year 2018/2019.

\section{References}

[1] B. Lipska, A. Palmowska, P. Ciuman, P. Koper, "Modelowanie numeryczne CFD w badaniach i projektowaniu rozdziału powietrza w pomieszczeniach wentylowanych (Numerical modelling CFD in the research and design of air distribution in ventilated rooms)," INSTAL, no. 3, pp. 33-43, 2015.

[2] G. Lombardi, M. Maganzi, F. Cannizzo, G. Solinas, "The Use of CFD to Improve the Thermal Comfort in the Automotive Field," in Proceedings of the 3rd European Automotive CFD Conference, The Best of Automotive CFD, Frankfurt, DE, 2007, pp. 225-237.

[3] A. Fujita, J. Kanemaru, H. Nakagawa, Y. Ozeki, "Numerical simulation method to predict the thermal environment inside a car cabin," JSAE Review, vol. 22, pp. 39-47, 2001.

[4] G. Sevilgen and M. Kiliç, "Investigation of transient cooling of an automobile cabin with a virtual manikin under solar radiation," Thermal Science, vol. 17, pp. 397-406, 2013.

[5] P. Danca, F. Bode, I. Nastase, A. Meslem, "CFD simulation of a cabin thermal environment with and without human body - thermal comfort evaluation," E3S Web of Conferences, vol. 32, 2018.

[6] P. Danca, F. Bode, I. Nastase, A. Meslem, "On the possibility of CFD modeling of the indoor environment in a vehicle, Energy Procedia, vol. 112, pp. 656-663, 2017.

[7] Y. Mao, J. Wang, J. Li, "Experimental and numerical study of air flow and temperature variations in an electric vehicle cabin during cooling and heating," Applied Thermal Engineering, vol. 137, pp. 356-367, 2018.

[8] M. Aliahmadipour , M. Abdolzadeh, K. Lari, "Air flow simulation of HVAC system in compartment of a passenger coach,” Applied Thermal Engineering, vol. 123, pp. 973-990, 2017.

[9] T. Plinninger and A. Hildebrandt, "Comfortable Rail Travel," Ansys Advantage, vol. XI, 2017.

[10] S. Jiangzhou, R.Z Wang, Y.Z Lu, Y.X Xu, J.Y Wu, "Experimental investigations on adsorption air-conditioner used in internal-combustion locomotive driver-cabin," Applied Thermal Engineering, vol. 22, pp. 1153-1162, 2002.

[11] S. Jiangzhou, R.Z Wang, Y.Z Lu, Y.X Xu, J.Y Wu, Z.H Li, "Locomotive driver cabin adsorption airconditioner,“ Renewable Energy, vol. 28, pp. 1659-1670, 2003.

[12] OECD (2019). Freight transport (indicator) [Online]. Available: https://data.oecd.org/transport/freighttransport.htm (Accessed on 19 January 2019). 
[13] Monitoring and Analysis Unit in the Railway Market Regulation Department (2019). Freight rail transport [Online]. Available:

https://www.utk.gov.pl/pl/raporty-i-analizy/analizy-i-monitoring/statystyka-przewozow-to/13957,Danepodstawowe.html (Accessed on 19 January 2019).

[14] EN 14813-1:2006: Railway Applications - Air conditioning for driving cabs - Part 1: Comfort parameters.

[15] G. Haller, "Thermal Comfort in Rail Vehicles," Vienna, 2006.

[16] EN 14813-2:2006: Railway Applications - Air conditioning for driving cabs - Part 2: Type tests.

[17] Z. Durzyński, Z. Marciniak, "Nowe rozwiązania konstrukcyjne w zmodernizowanej lokomotywie elektrycznej ET22-2000 (New technical solution in modernised electric locomotive class ET22)," TTS Technika Transportu Szynowego, no. 12, pp. 33-40, 2004.

[18] Technical documentation of KLIL 22 air conditioner. 